\title{
Peripheral blood lymphocyte responses to cytomegalovirus seropositivity after allogeneic- hematopoietic stem cell transplantation
}

This article was published in the following Dove Press journal:

OncoTargets and Therapy

\author{
Jiexin Zhang ${ }^{1,2, *}$ \\ Xian Chen ${ }^{1,2, *}$ \\ Guodong Rong ${ }^{1,2}$ \\ Ting $X u^{1,2}$ \\ Hong Zhao ${ }^{1,2}$ \\ Dan Chen ${ }^{1,2}$ \\ Lei $\mathrm{Wu}^{1,2}$ \\ Peijun Huang ${ }^{1,2}$ \\ Fang Wang ${ }^{1,2}$
}

'Department of Laboratory Medicine, The First Affiliated Hospital of Nanjing Medical University, 210029 ,

Nanjing, China; ${ }^{2}$ National Key Clinical Department of Laboratory Medicine, 210029, Nanjing, China

*These authors contributed equally to this work
Correspondence: Peijun Huang; Fang Wang

Department of Laboratory Medicine, First Affiliated Hospital of Nanjing Medical University, Number 300

Guangzhou Road, Nanjing 210029, China

$\mathrm{Tel} / \mathrm{fax}+8625$ 837। 8836;

+862586862814

Email hpj63@।63.com;

wangfang@njmu.edu.cn
Background: The main purpose of this study was to investigate the relationship among cytomegalovirus (CMV) viremia, peripheral immune cells alternations, and leukemia prognosis. Patients and methods: We studied 90 leukemia patients who underwent allogeneic hematopoietic stem cell transplantation (allo-HSCT) from 2008 to 2015. Their complete clinical laboratory data were collected until 1 year after transplantation.

Results: All patients were serum CMV negative before allo-HSCT. After transplantation, the $\mathrm{CMV}$ reactivation group showed increased peripheral $\mathrm{CD} 8^{+} \mathrm{T}$ cells and decreased $\mathrm{CD} 4^{+} \mathrm{T}$ cells and B cells. However, CD8/CD4 ratio and B cells restored by control of CMV infection due to 2 months maximum course of ganciclovir treatment. CMV seropositivity was positively related to leukemia-free survival (LFS) of all recruited leukemia types.

Conclusion: In summary, CMV drives immune cell post-transplantation fluctuation, which also favors LFS of leukemia partly resulted from $\mathrm{CD}^{+} \mathrm{T}$ cells.

Keywords: cytomegalovirus, leukemia, allo-HSCT, CD8 ${ }^{+} \mathrm{T}$ cells, leukemia-free survival

\section{Introduction}

Cytomegalovirus (CMV) is a common double-stranded DNA herpes virus. Infection by CMV induces few, if any, clinical symptoms in healthy people. ${ }^{1}$ This virus may not ever be reactivated except for immune suppression circumstances, such as stem cell transplantation or human immunodeficiency virus infection. CMV can be detected from serum of leukemia patients early after transplantation, which are susceptible to CMV infection, and develop CMV pneumonia with highly mortality. ${ }^{2-5}$

Allogeneic hematopoietic stem cell transplantation (allo-HSCT) has been widely applied as a recommended first-line therapy for leukemia. Before transplantation, patients receive chemotherapy to destroy tumor cells as well as immune system to make room for new stem cells for restoring hematopoiesis. To prevent CMV infection during therapy, patients are simultaneously designated antiviral drug, such as ganciclovir (GCV). Nevertheless, CMV still emerges in serum as early as a few days after transplantation. Moreover, some studies indicated that pre-surgery chemotherapy and GCV administration will impel patients more frail to CMV infection due to its side effects of myelosuppression, and postpone reconstitution of $\mathrm{CMV}$-specific cellular immunity by suppressing proliferation of $\mathrm{T}$ cells as well as CMV-specific T-cell precursors. ${ }^{6,7}$

Immune system plays a significant role in controlling virus infection, survival, and proliferation. For example, $\mathrm{CD} 4^{+} \mathrm{T}$-helper (Th) cells secrete interferon- $\gamma$, tumor necrosis factor- $\alpha$, and interleukin- 2 to exert a Th1-type immune reaction to eliminate 
virus. ${ }^{8}$ Natural killer (NK) cell-expressed killer cell Ig-like receptor and $\mathrm{NKG} 2 \mathrm{C}$ subsets contribute to graft versus leukemia effect. ${ }^{9}$ It has been reported that CMV reactivation reduces the risk of relapse in acute myeloid leukemia (AML) patients until 100 days after transplantation. ${ }^{10}$ These studies prompted us to further investigate the interplay between CMV post-surgery seropositivity and immune status in leukemia patients who undergo allo-HSCT and to discuss the factors that may influence their clinical prognosis.

\section{Materials and methods} Patient characteristics

This research was authorized by the Ethical Committee of the First Affiliated Hospital of Nanjing Medical University (Nanjing, China). All patients provided written informed consent. Patients diagnosed with AML, acute lymphoblastic leukemia (ALL), chronic granulocytic leukemia (CML), lymphoma, chronic lymphocytic leukemia (CLL), myelodysplastic syndrome (MDS), and other undefined leukemia in 2008-2015 were identified. Key exclusion criteria included allo-HSCT more than one time and serum CMV positive before allo-HSCT. All enrolled 90 leukemia patients were divided into $\mathrm{CMV}+$ group and $\mathrm{CMV}$ - group according to post-transplantation serum CMV DNA load. Follow-up ended on April 30, 2016, with a survey range of 1.5-98.6 months after transplantation (median: 15.9 months); 25 patients were finally lost to follow-up.

\section{Fluorescence-activated cell sorting (FACS)}

FACS detection was carried out on peripheral blood samples on the very first day of admission till 1 year after allo-HSCT. Whole blood cells were conjugated to antibodies including CD3, CD4, CD8, CD16, CD19, and CD56 (BioLegend, San Jose, CA, USA) at room temperature. Samples were incubated for 20 minutes in the dark. Then red blood cells were lysed by lysis buffer (BD Biosciences, San Jose, CA, USA). The remaining cells were washed with PBS for three times and were measured by flow cytometry (BD Calibur; BD Biosciences). Different gate settings were used to distinguish lymphocyte subsets. The FACS results indicated the percentages of $\mathrm{CD}^{+} \mathrm{T}$ cells, $\mathrm{CD} 8^{+} \mathrm{T}$ cells, NK cells, and B cells.

\section{CMV detection}

We detected serum CMV DNA load via quantitative polymerase chain reaction following manufacturer's instructions (Daan Gene, Sun Yat-Sen University, China). This experiment was applied for each patient before surgery and weekly after surgery until CMV seroconversion. The lower threshold of this assay is 500 genome copies per $\mathrm{mL}$ blood
(c/mL); the upper limit is 50,000,000 c/mL. Serum CMV DNA load $<500 \mathrm{c} / \mathrm{mL}$ was defined CMV negative.

\section{GVHD prophylaxis}

GVHD prophylaxis primarily comprises cyclosporine A (CSA) and methotrexate (MTX), or CSA + MTX with other immunosuppressants (mycophenolate mofetil, basiliximab). All patients received GVHD prophylaxis before transplantation. Diagnosis of acute GVHD was based on clinical signs and symptoms and laboratory studies. Acute GVHD was graded using accepted criterion; ${ }^{11}$ chronic GVHD was graded according to NIH criterion. ${ }^{12}$

\section{Clinical definition}

Overall survival (OS) was defined as the number of days from the date of transplantation to the date of death from any cause or the last date of follow-up. Leukemia-free survival (LFS) was counted from the date of surgery to the date of leukemia relapse or to the date of follow-up without relapse.

\section{Statistical analysis}

Fisher's exact test or the chi-square test was used to analyze the clinical parameters. Multivariate analyses were conducted using the Cox proportional hazards model to evaluate the risk factors for LFS. Kaplan-Meier survival analysis was used to estimate the rates of OS, and the log-rank test was applied to each group. All data were analyzed with IBM SPSS Statistics for Windows 17.0. $P$-values less than 0.05 were considered significant.

\section{Results \\ Patient characteristics}

Serum CMV DNA load of all 90 patients before allo-HSCT was beyond the detection limit, among which 54 patients (60\%) acquired CMV infection after transplantation. Their other clinical parameters are shown in Table 1. Patients with HLA-matched siblings donors received a stronger immunosuppression drug treatment, or patients who had acute GVHD (aGVHD) were more susceptible to CMV post-surgery infection.

\section{CMV seropositivity after allo-HSCT} alters peripheral immune cell distribution We analyzed percentages of peripheral $\mathrm{CD}^{+} \mathrm{T}$ cells, $\mathrm{CD} 8^{+}$ $\mathrm{T}$ cells, NK cells, and $\mathrm{B}$ cells in the CMV+ and CMVgroups, respectively. As shown in Figure 1, $\mathrm{CD}^{+} \mathrm{T}$ cells were significantly downregulated and $\mathrm{CD} 8^{+} \mathrm{T}$ cells were highly upregulated in the CMV+ group, which led to obviously upregulated $\mathrm{CD} 8 / \mathrm{CD} 4$ ratio. $\mathrm{B}$ cells were lower in the $\mathrm{CMV+}$ group compared with the CMV- group. No difference was 
Table I Clinical characteristics of 90 leukemia patients in the CMV+ and CMV-groups

\begin{tabular}{|c|c|c|c|c|}
\hline Variables & Patients & CMV+ group & CMV-group & $P$-value \\
\hline Patients & 90 & $54(60 \%)$ & $36(40 \%)$ & \\
\hline Sex & & & & 0.7 \\
\hline Female/male & $46 / 44(51 \%)$ & $27 / 27(50 \%)$ & $19 / 17(53 \%)$ & \\
\hline Age & $35.5(6-65)$ years & $35(6-60)$ years & $4 \mid(9-65)$ years & 0.9 \\
\hline \multicolumn{5}{|l|}{ Diagnosis } \\
\hline AML & $36(40 \%)$ & $22(40.7 \%)$ & I4 (38.9\%) & \\
\hline ALL & 14 (I5\%) & $10(18.5 \%)$ & $4(I 1.1 \%)$ & \\
\hline CML & $8(9 \%)$ & $4(7.4 \%)$ & $4(11.1 \%)$ & \\
\hline RBC leukemia & $6(7 \%)$ & 4 (7.4\%) & $2(5.5 \%)$ & \\
\hline Lymphoma & $14(16 \%)$ & $5(9.3 \%)$ & $9(25 \%)$ & \\
\hline CLL & $2(2 \%)$ & $2(3.7 \%)$ & $0(0 \%)$ & \\
\hline MDS & $9(10 \%)$ & 7 (13\%) & $2(5.6 \%)$ & \\
\hline Others & $\mathrm{I}(\mathrm{l} \%)$ & $0(0 \%)$ & I (2.8\%) & \\
\hline Conditioning regimen & & & & 0.1 \\
\hline MAC & $68(75.5 \%)$ & $45(83.3 \%)$ & $23(63.9 \%)$ & \\
\hline RIC & $15(16.7 \%)$ & 7 (I3\%) & $8(22.2 \%)$ & \\
\hline Others & $7(7.8 \%)$ & $2(3.7 \%)$ & $5(13.9 \%)$ & \\
\hline Donors & & & & 0.003 \\
\hline HLA-matched siblings & $62(68.9 \%)$ & $33(61.1 \%)$ & $29(80.5 \%)$ & \\
\hline Unrelated matched & $20(22.2 \%)$ & 18 (33.3\%) & $2(5.6 \%)$ & \\
\hline Unknown & $8(8.9 \%)$ & $3(5.6 \%)$ & 5 (13.9\%) & \\
\hline Stem cell source & & & & 0.143 \\
\hline $\mathrm{PB}+\mathrm{CB}$ & 10 (II\%) & 7 (I2.9\%) & $3(8.3 \%)$ & \\
\hline PB & $76(84 \%)$ & $42(77.8 \%)$ & $33(91.7 \%)$ & \\
\hline $\mathrm{CB}$ & $3(3 \%)$ & $3(5.6 \%)$ & $0(0 \%)$ & \\
\hline Unknown & $2(2 \%)$ & $2(3.7 \%)$ & $0(0 \%)$ & \\
\hline GVHD prophylaxis & & & & 0.03 \\
\hline CSA/MTX & 82 (91.1\%) & $52(96.3 \%)$ & $30(83.3 \%)$ & \\
\hline ATG or other & $8(8.9 \%)$ & $2(3.7 \%)$ & $6(16.7 \%)$ & \\
\hline GVHD & & & & 0.009 \\
\hline Acute GVHD & $43(47.8 \%)$ & $34(62.9 \%)$ & $9(25 \%)$ & \\
\hline Chronic GVHD & $16(17.8 \%)$ & $7(12.9 \%)$ & $9(25 \%)$ & \\
\hline Status & & & & 0.19 \\
\hline Relapse & $13(14.4 \%)$ & $7(7.8 \%)$ & $6(6.7 \%)$ & \\
\hline Dead & $16(17.8 \%)$ & $7(7.8 \%)$ & $9(6.7 \%)$ & \\
\hline Missing & $24(26.7 \%)$ & $16(17.8 \%)$ & $8(8.9 \%)$ & \\
\hline
\end{tabular}

Abbreviations: ALL, acute lymphoblastic leukemia; AML, acute myeloid leukemia; ATG, Anti-human Thymocyte Globulin; CB, stem cells from cord blood; CLL, chronic lymphocytic leukemia; CML, chronic granulocytic leukemia; CMV, cytomegalovirus; CSA, Cyclosporin A; GVHD, graft-versu-host disease; HLA, human lymphocyte antigen; MAC, Myeloablative stem cell transplantation; MDS, myelodysplastic syndrome; MTX, Methotrexate; PB, stem cells from peripheral blood; RIC, Reduce-intensity conditioning.

found in NK cells. We further analyzed the data of AML patients and found similar trends, as shown in Figure 2. These results suggest that CMV affects immune cells posttransplantation distribution, and that $\mathrm{CD} 8^{+} \mathrm{T}$ cells dominate in peripheral blood.

\section{Control of CMV infection induces} peripheral immune cell re-distribution

Severe CMV infection often occurred within the first 100 days after allo-HSCT. ${ }^{13}$ The median time of CMV seropositivity in our leukemia patients was 38.5 days (range: $2-102$ days)
A

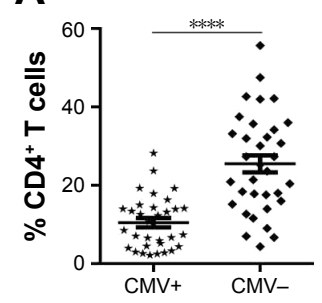

B

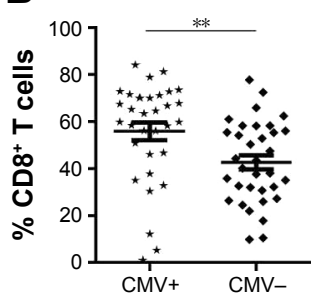

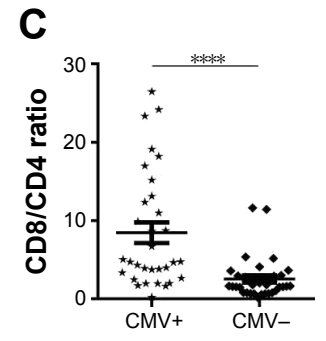

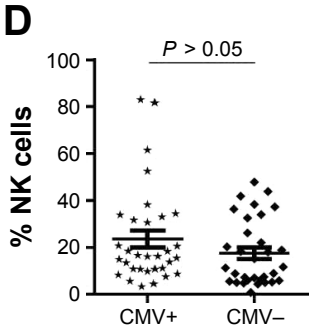

Figure I CMV seropositivity after allo-HSCT alters peripheral immune cells distribution.

Notes: Serum CMV DNA load was detected via real-time PCR I week after allo-HSCT. Patients suffered from CMV seropositivity defined as CMV+ group, otherwise CMV- group. The percentages of peripheral CD4 $4^{+}$T cells $(\mathbf{A}), C D 8^{+} \mathrm{T}$ cells $(\mathbf{B})$, ratio of CD8/CD4 (C), NK cells (D), and B cells $(\mathbf{E})$ of leukemia patients in the CMV+ and CMV- groups. Graphs show mean \pm SEM. $* P<0.05$; **P $<0.01 ; * * * * P<0.000$ I.

Abbreviations: allo-HSCT, allogeneic hematopoietic stem cell transplantation; CMV, cytomegalovirus; NK, natural killer. 
A

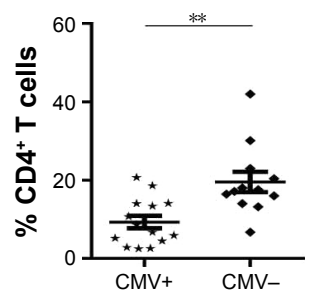

B

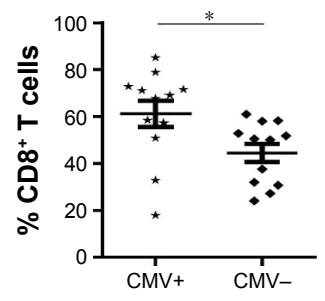

C

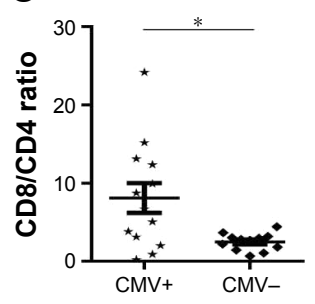

D

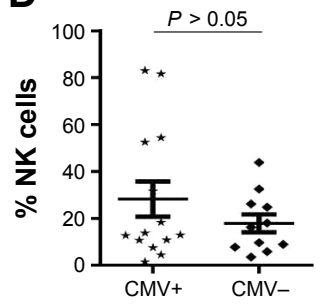

E

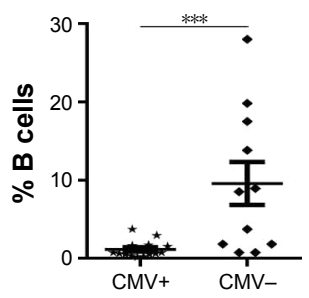

Figure 2 Peripheral immune cell distributions in AML patients with CMV seropositivity after allo-HSCT.

Notes: Representative data of circuiting CD4 ${ }^{+} \mathrm{T}$ cells $(\mathbf{A}), \mathrm{CD} 8^{+} \mathrm{T}$ cells $(\mathbf{B})$, ratio of CD8/CD4 (C), NK cells (D), and B cells (E) in AML patients with CMV infection after transplantation. All the graphs show mean \pm SEM. $* P<0.05$; $* * P<0.0$ I; $* * * P<0.00$ I.

Abbreviations: allo-HSCT, allogeneic hematopoietic stem cell transplantation; AML, acute myeloid leukemia; CMV, cytomegalovirus; NK, natural killer.

within the CMV+ group. We weekly monitored peripheral CMV genome copies of these patients after allo-HSCT and documented the first date of CMV seropositivity and 2 months after the date, respectively, to investigate immune cell responses to GCV administration. We successively collected results of 18 patients in the $\mathrm{CMV}+$ group. As shown in Figure 3, $\mathrm{CD} 8^{+} \mathrm{T}$ cells, $\mathrm{CD} 4^{+} \mathrm{T}$ cells, and $\mathrm{B}$ cells were restored when serum CMV was negatively converted, and the $\mathrm{CD} 8 / \mathrm{CD} 4$ ratio dropped back to the baseline.

Next, we extended the follow-up period to 12 months after allo-HSCT and analyzed flow cytometry data of all patients in the CMV+ group. Their serum CMV all turned negative (if infection occurred) within 2 months after courses of GCV administration. Alteration of $\mathrm{CD}^{+} \mathrm{T}$ cells, $\mathrm{CD} 8^{+}$ $\mathrm{T}$ cells, and $\mathrm{B}$ cells significantly occurred from 1 month to 3 months post-surgery (Figure 4). However, these differences between the CMV+ and CMV- groups became less pronounced with elongated follow-up time. Distribution of peripheral immune cells restored to pre-transplantation at as early as 6 months. These results indicated that CMV drives immune cells' post-transplantation fluctuation.

\section{CMV seropositivity affects leukemia prognosis after allo-HSCT}

Totally, 13 patients suffered leukemia relapse after alloHSCT. The median relapse time was 262 days ( 8.7 months).
As shown in Table 2, both prophylactic GVHD treatment and occurrence of aGVHD were risk factors of LFS. As reported, CMV reactivation protected AML patients from relapse within 100 days post-transplantation. ${ }^{10}$ Therefore, we excluded the data of AML patients and further investigated the influence of CMV on other leukemia types. As shown in Table 3, CMV seropositivity was positively correlated with their LFS, indicating the favorable effect of CMV on leukemia overall prognosis.

CMV seropositivity, as well as stem cell sources, was positively correlated with LFS, although the overall survival of the CMV+ group was approximately to that of the CMVgroup (53.10 months vs 59.21 months; $P=0.24$; Figure 5). It indicated that CMV seropositivity may rescue leukemia patients, but it cannot extend their length of survival probably due to its control failure of peripheral immune system in the long-term.

\section{Discussion}

CMV often "hides" in hematopoietic progenitors. ${ }^{14}$ Along with the differentiation and maturation of these progenitors, CMV amplifies. Some suggested that latent virus can be reactivated by the allogeneic monocyte-derived macrophages. ${ }^{15}$ Therefore, peripheral blood mononuclear cells are believed to serve as CMV carriers. ${ }^{16}$ In this study, we elaborately collected data of 90 leukemia patients who were diagnosed
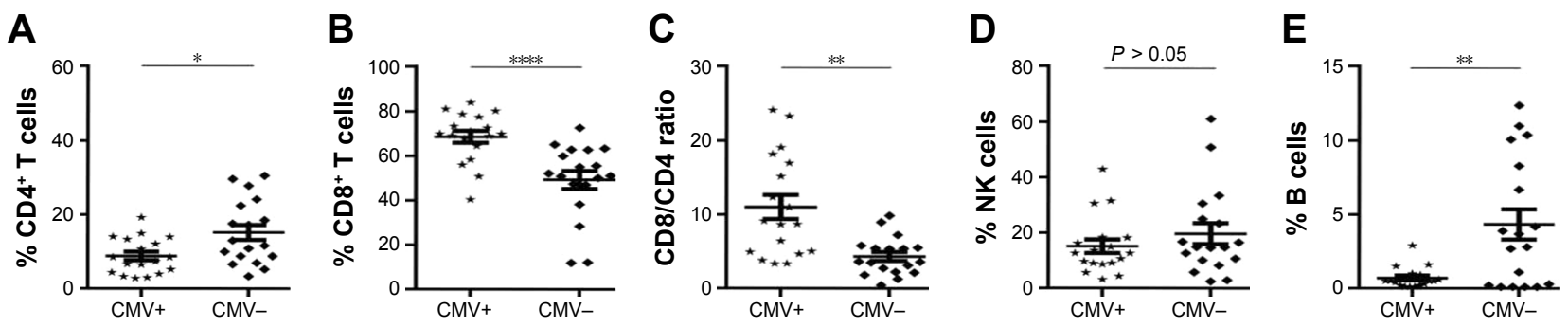

Figure 3 Control of CMV infection induces peripheral immune cell re-distribution.

Notes: In total, 54 leukemia patients had CMV reactivation after allo-HSCT, among which 18 patients' cytometry data were continuously collected after their serum CMVnegative conversion 2 months later by GCV administration. Statistical analysis represented their peripheral CD4+ T cells (A), CD8 ${ }^{+}$T cells (B), CD8/CD4 ratio (C), NK cells (D), and B cells (E). $* P<0.05$; **P $<0.01$; ****P $<0.000$ I. All the graphs show mean \pm SEM.

Abbreviations: allo-HSCT, allogeneic hematopoietic stem cell transplantation; CMV, cytomegalovirus; NK, natural killer. 

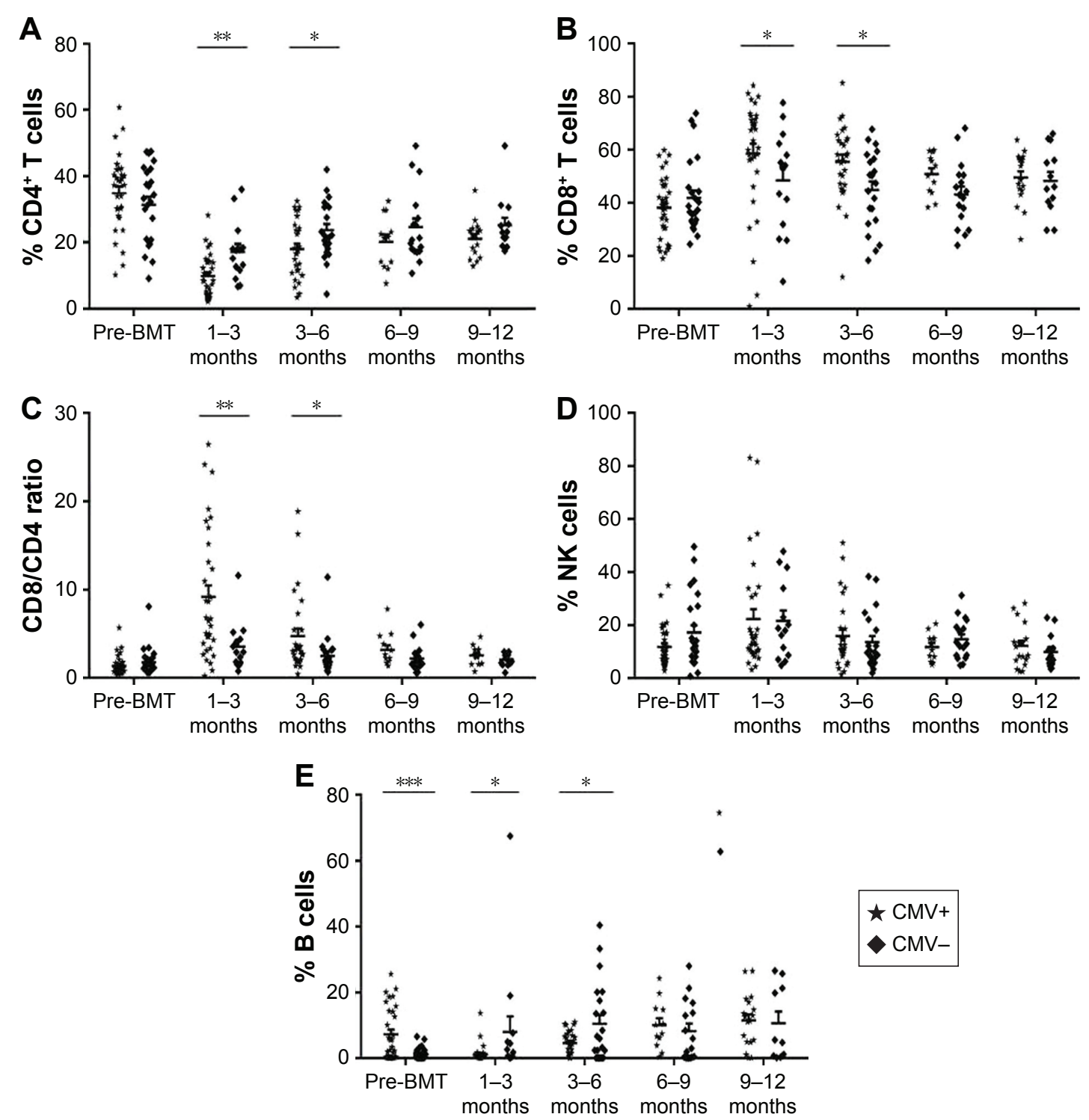

Figure 4 Distribution of peripheral immune cells during 12 months' follow-up in all 90 leukemia patients after allo-HSCT.

Notes: We recorded their serum CMV load and correspondent flow cytometry data. Those with incomplete data were removed from the pool. Lymphocyte distribution was described in the time points of pre-BMT, I-3 months (CMV seropositivity), 3-6 months (CMV negatively converted by GCV), 6-9 months, and 9-I2 months. Representative dot plots of the percentages with circuiting CD4+ T cells (A), CD8 ${ }^{+} \mathrm{T}$ cells (B), CD8/CD4 ratio (C), NK cells (D), and B cells (E) in CMV+ group and CMV- group. All the statistical graphs show mean \pm SEM. $* P<0.05$; $* * P<0.0$ I; ***P $<0.00$ I.

Abbreviations: allo-HSCT, allogeneic hematopoietic stem cell transplantation; BMT, bone marrow transplantation; CMV, cytomegalovirus; GCV, Ganciclovir; NK, natural killer.

Table 2 Clinical parameters related to LFS in 65 leukemia patients by multivariate variable Cox regression

\begin{tabular}{llll}
\hline Parameters & $\begin{array}{l}\text { Hazard } \\
\text { ratio }\end{array}$ & $\mathbf{9 5 \%} \mathbf{C l}$ & P-value \\
\hline CMV seropositivity & 2.293 & $1.136-4.629$ & 0.021 \\
Age & 1.196 & $0.662-2.300$ & 0.591 \\
Sex & 0.627 & $0.348-1.130$ & 0.120 \\
Diagnosis & 1.214 & $0.976-1.510$ & 0.081 \\
Conditioning regimen & 0.810 & $0.456-2.736$ & 0.810 \\
Stem cell sources & 2.006 & $1.253-3.211$ & 0.004 \\
GVHD prophylactic & 0.097 & $0.011-0.884$ & 0.038 \\
aGVHD & 0.526 & $0.280-0.991$ & 0.047 \\
\hline
\end{tabular}

Abbreviations: aGVHD, acute GVHD; CMV, cytomegalovirus; GVHD, graftversu-host disease; LFS, leukemia-free survival.
Table 3 Clinical parameters associated with LFS in other leukemia patients, except for AML, by multivariate Cox regression analysis

\begin{tabular}{llll}
\hline Parameters & $\begin{array}{l}\text { Hazard } \\
\text { ratio }\end{array}$ & $\mathbf{9 5 \%} \mathbf{C l}$ & $P$-value \\
\hline CMV seropositivity & 3.384 & $1.196-9.575$ & 0.022 \\
Age & 1.123 & $0.411-3.072$ & 0.821 \\
Sex & 1.083 & $0.424-2.765$ & 0.868 \\
Conditioning regimen & 0.754 & $0.240-2.367$ & 0.629 \\
Stem cell sources & 2.550 & $0.816-7.969$ & 0.108 \\
GVHD prophylactic & 0.126 & $0.006-2.535$ & 0.176 \\
aGVHD & 0.367 & $0.132-1.021$ & 0.055 \\
\hline
\end{tabular}

Abbreviations: aGVHD, acute GVHD; AML, acute myeloid leukemia; CMV, cytomegalovirus; GVHD, graft-versu-host disease; LFS, leukemia-free survival. 


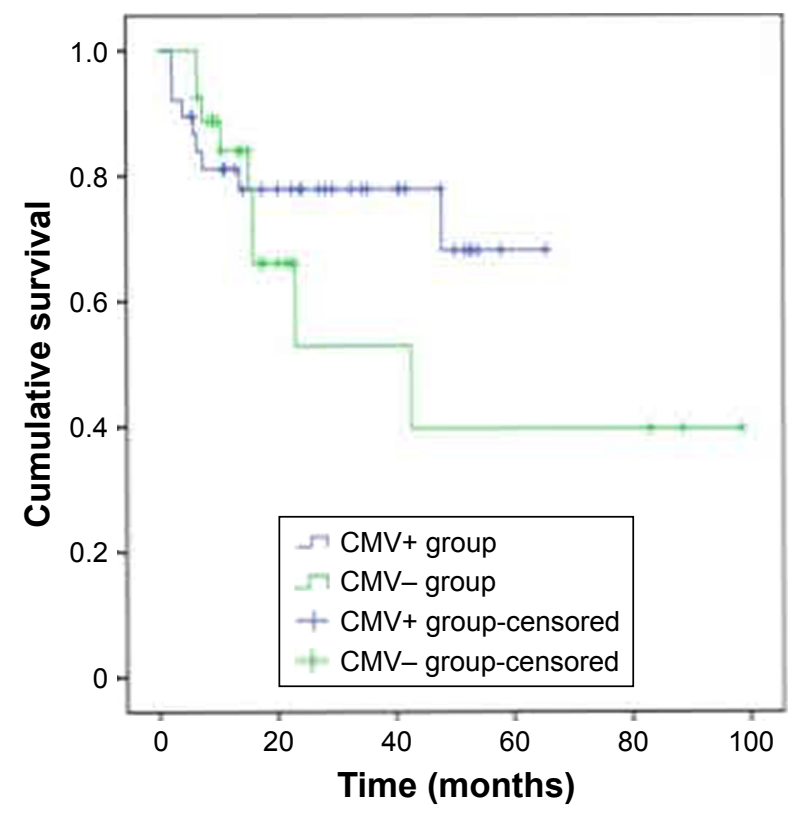

Figure 5 Overall survival curve of 65 leukemia patients. Abbreviation: CMV, cytomegalovirus.

with AML, ALL, CML, CLL, MDS, and other undefined leukemia and had been determined CMV-free to standardize comparison criteria before allo-HSCT. Our data showed that the number of $\mathrm{CD}^{+} \mathrm{T}$ cells and the $\mathrm{CD} 8 / \mathrm{CD} 4$ ratio were statistically higher in the CMV+ group, consistent with other study referring to $\mathrm{CMV}$ reactivation after transplantation, suggesting that post-surgery serum CMV status is closely related to peripheral immune cell alternation. $\mathrm{CD}^{+} \mathrm{T}$-cell and $\mathrm{CD}^{+}{ }^{+} \mathrm{T}$-cell restoration after subsequent $\mathrm{CMV}$ seroconversion by GCV administration further confirms that CMV had impact on the human peripheral immune system in our study.

Another important finding in our study is that CMV seropositivity was positively related to LFS of patients regardless of leukemia types. It was supposed to be related to functional $\mathrm{CD}^{+} \mathrm{T}$ cells for exerting cytotoxic effects in resisting chronic virus invasion and expansion of the renewed clone, ${ }^{17,18}$ and likewise for its peripheral domination after CMV seropositivity in our study. Higher CD8 ${ }^{+} \mathrm{T}$ cells have been reported, but with increased $\mathrm{CD}^{+} \mathrm{T}$ cells in CLL patients. ${ }^{19} \mathrm{CMV}$-specific $\mathrm{CD}^{+} \mathrm{T}$ cells express relatively lower inhibitory markers PD-1 and CD160, and they maintain conventional virus-specific cytotoxicity by $\mathrm{CD}_{45 \mathrm{RA}}{ }^{+} \mathrm{CD} 27^{+}$ phenotype. ${ }^{17,20} \mathrm{CMV}$-specific $\mathrm{CD}^{+} \mathrm{T}$ cells promote cytotoxic T-cell activity though Th1 cytokines and activation of antigenpresenting cells. ${ }^{21,22}$ They also play an important role in CMV-specific CD8 ${ }^{+}$cytotoxic T-lymphocyte differentiation and expansion via dendritic cell stimulation. ${ }^{23,24}$ Considering
$\mathrm{CD}^{+} \mathrm{T}$ cells were not numerically increased in the CMV+ group in this study, it is worth exploring whether ratios of each subtype of $\mathrm{CD}^{+} \mathrm{T}$ cells alter correspondingly. Recently, Scheper et al found that gamma delta T cells $(\gamma \delta \mathrm{T})$ initiated by CMV infection after allo-HSCT cross-recognized both CMVinfected cells and primary leukemia blasts, indicating that CMV is a warrior against leukemia. ${ }^{25}$ The interplay between $\gamma \delta \mathrm{T}$ cells and CMV infection seems to be a plausible explanation for the advantageous clinical prognosis. ${ }^{26}$ Mycophenolate mofetil affects viral replication by altering cytokine profiles and modulating adhesion-related molecules mediated by CMV, but it impairs both T and B cells' proliferation. ${ }^{27,28}$ Still, fewer $\mathrm{CD}^{+} \mathrm{T}$ cells can induce $\mathrm{T}-\mathrm{B}$ collaboration and reduce chronic GVHD (cGVHD) incidence. Moreover, CMV seropositivity increases the expression of leukocyte fixation antigen-3 on CMV-infected leukemia blasts and enhances NK cell-mediated blasts lysis without an increase in amount. ${ }^{29,30}$ Our data that $\mathrm{CD} 19^{+} \mathrm{B}$ cells reconstituted until 6 months after transplantation in the CMV+ group are consistent with the opinion that both aGVHD and cGVHD inhibit B cell reconstitution and delay B-cell immune recovery. ${ }^{6}$

Leukemia patients who receive peripheral blood stem cells will acquire donor-derived passive immunity, whereas cord blood stem cells are immunological naïve, and upon activation, donor-derived T cells will aim at CMV lesion and directly exert cytotoxic effects towards leukemia blasts expressing CMV-related antigens. Unfortunately, the wide use of ATG in leukemia patients who are ready to receive cord blood stem cell transplantation messes with the recipient-derived immune cells, and this may be vital to post-surgery immune response especially encountering CMV infection. ${ }^{31}$

\section{Conclusion}

Here, we reported the alternations of peripheral immune cells, including $\mathrm{CD}^{+}{ }^{+} \mathrm{T}$ cells, $\mathrm{CD} 8^{+} \mathrm{T}$ cells, NK cells, and $\mathrm{B}$ cells, responses to CMV seropositivity of leukemia patients after allo-HSCT. Leukemia patients may benefit from CMV seropositivity on LFS aspect, probably due to the immune constitution of peripheral $\mathrm{CD}^{+} \mathrm{T}$ cells. Further, how to maintain functional and long-run peripheral $\mathrm{CD}^{+} \mathrm{T}$ cells after allo-HSCT may be a promising alternative therapeutic regimen in individualized prognosis.

\section{Acknowledgments}

We are grateful for the technical support from the National Key Clinical Department of Laboratory Medicine of Jiangsu Province Hospital. This study was supported by "The Six Top 
Talent Project" of Jiangsu Province (number 2015-WSN034), Jiangsu Province's Key Provincial Talents Program (number ZDRCA2016003), Natural Science Youth Foundation of China under grant (number 81501817), Natural Science Youth Foundation of Jiangsu Province under grant (number BK20151029), Key Laboratory for Medicine of Jiangsu Province of China (number ZDXKB2016005), and a project funded by the Priority Academic Program Development of Jiangsu Higher Education Institutions.

\section{Disclosure}

The authors report no conflicts of interest in this work.

\section{References}

1. Rafailidis PI, Mourtzoukou EG, Varbobitis IC, Falagas ME. Severe cytomegalovirus infection in apparently immunocompetent patients: a systematic review. Virolo J. 2008;5:47.

2. Nakamura R, Battiwalla M, Solomon S, et al. Persisting posttransplantation cytomegalovirus antigenemia correlates with poor lymphocyte proliferation to cytomegalovirus antigen and predicts for increased late relapse and treatment failure. Biol Blood Marrow Transplant. 2004; 10(1):49-57.

3. Nichols WG, Corey L, Gooley T, Davis C, Boeckh M. High risk of death due to bacterial and fungal infection among cytomegalovirus (CMV)-seronegative recipients of stem cell transplants from seropositive donors: evidence for indirect effects of primary CMV infection. J Infect Dis. 2002;185(3):273-282.

4. Boeckh M, Nichols WG, Papanicolaou G, Rubin R, Wingard JR, Zaia J. Cytomegalovirus in hematopoietic stem cell transplant recipients: current status, known challenges, and future strategies. Biol Blood Marrow Transplant. 2003;9(9):543-558.

5. Matsumura T, Narimatsu H, Kami M, et al. Cytomegalovirus infections following umbilical cord blood transplantation using reduced intensity conditioning regimens for adult patients. Biol Blood Marrow Transplant. 2007;13(5):577-583.

6. Foster AE, Gottlieb DJ, Sartor M, Hertzberg MS, Bradstock KF. Cytomegalovirus-specific CD4+ and CD8+ T-cells follow a similar reconstitution pattern after allogeneic stem cell transplantation. Biol Blood Marrow Transplant. 2002;8(9):501-511.

7. Li CR, Greenberg PD, Gilbert MJ, Goodrich JM, Riddell SR. Recovery of HLA-restricted cytomegalovirus (CMV)-specific T-cell responses after allogeneic bone marrow transplant: correlation with CMV disease and effect of ganciclovir prophylaxis. Blood. 1994;83(7):1971-1979.

8. Pourgheysari B, Bruton R, Parry H, et al. The number of cytomegalovirus-specific CD4+ $\mathrm{T}$ cells is markedly expanded in patients with B-cell chronic lymphocytic leukemia and determines the total CD4+ T-cell repertoire. Blood. 2010;116(16):2968-2974.

9. Djaoud Z, David G, Bressollette C, et al. Amplified NKG2C+ NK cells in cytomegalovirus (CMV) infection preferentially express killer cell Ig-like receptor 2DL: functional impact in controlling CMV-infected dendritic cells. J Immunol. 2013;191(5):2708-2716.

10. Elmaagacli AH, Steckel NK, Koldehoff M, et al. Early human cytomegalovirus replication after transplantation is associated with a decreased relapse risk: evidence for a putative virus-versus-leukemia effect in acute myeloid leukemia patients. Blood. 2011;118(5): 1402-1412.

11. Glucksberg H, Storb R, Fefer A, et al. Clinical manifestations of graftversus-host disease in human recipients of marrow from HL-A-matched sibling donors. Transplantation. 1974;18(4):295-304.
12. Filipovich AH, Weisdorf D, Pavletic S, et al. National Institutes of Health consensus development project on criteria for clinical trials in chronic graft-versus-host disease: I. Diagnosis and staging working group report. Biol Blood Marrow Transplant. 2005;11(12):945-956.

13. Green ML, Leisenring WM, Xie $\mathrm{H}$, et al. CMV reactivation after allogeneic HCT and relapse risk: evidence for early protection in acute myeloid leukemia. Blood. 2013;122(7):1316-1324.

14. Alexander R, Lamb D, White D, et al. "RETCIF": a rapid, sensitive method for detection of viruses, applicable for large numbers of clinical samples. J Virol Methods. 2001;97(1-2):77-85.

15. Liu WT, Sun JR, Lin CH, Kuo RL, Kung SH. An indicator cell assay for detection of human cytomegalovirus based on enhanced green fluorescent protein. J Virol Methods. 2001;96(1):85-92.

16. Morello CS, Cranmer LD, Spector DH. In vivo replication, latency, and immunogenicity of murine cytomegalovirus mutants with deletions in the M83 and M84 genes, the putative homologs of human cytomegalovirus pp65 (UL83). J Virol. 1999;73(9):7678-7693.

17. Mackus WJ, Frakking FN, Grummels A, et al. Expansion of CMVspecific CD8+CD45RA+CD27- T cells in B-cell chronic lymphocytic leukemia. Blood. 2003;102(3):1057-1063.

18. Gonzalez-Rodriguez AP, Contesti J, Huergo-Zapico L, et al. Prognostic significance of CD8 and CD4 T cells in chronic lymphocytic leukemia. Leuk Lymphoma. 2010;51(10):1829-1836.

19. Pourgheysari B, Bruton R, Parry H, et al. The number of cytomegalovirus-specific CD4+ T cells is markedly expanded in patients with B-cell chronic lymphocytic leukemia and determines the total CD4+ T-cell repertoire. Blood. 2010;116(16):2968-2974.

20. te Raa GD, Pascutti MF, García-Vallejo JJ, et al. CMV-specific CD8+ T-cell function is not impaired in chronic lymphocytic leukemia. Blood. 2014;123(5):717-724.

21. Shedlock DJ, Shen H. Requirement for CD4 T cell help in generating functional CD8 T cell memory. Science. 2003;300(5617):337-339.

22. Lanzavecchia A, Sallusto F. Dynamics of T lymphocyte responses: intermediates, effectors, and memory cells. Science. 2000;290(5489): 92-97.

23. Ridge JP, Di Rosa F, Matzinger P. A conditioned dendritic cell can be a temporal bridge between a CD4+ T-helper and a T-killer cell. Nature. 1998;393(6684):474-478.

24. Schoenberger SP, Toes RE, van der Voort EI, Offringa R, Melief CJ. T-cell help for cytotoxic T lymphocytes is mediated by CD40-CD40L interactions. Nature. 1998;393(6684):480-483.

25. Larosa F, Marmier C, Robinet E, et al. Peripheral T-cell expansion and low infection rate after reduced-intensity conditioning and allogeneic blood stem cell transplantation. Bone Marrow Transplant. 2005; 35(9):859-868.

26. Scheper W, van Dorp S, Kersting S, et al. $\gamma \delta T$ cells elicited by CMV reactivation after allo-SCT cross-recognize CMV and leukemia. Leukemia. 2013;27(6):1328-1338.

27. Lipsky JJ. Mycophenolate mofetil. Lancet. 1996;348(9038): 1357-1359.

28. Heemann U, Azuma H, Hamar P, Schmid C, Tilney N, Philipp T. Mycophenolate mofetil inhibits lymphocyte binding and the upregulation of adhesion molecules in acute rejection of rat kidney allografts. Transpl Immunol. 1996;4(1):64-67.

29. Fletcher JM, Prentice HG, Grundy JE. Natural killer cell lysis of cytomegalovirus (CMV)-infected cells correlates with virally induced changes in cell surface lymphocyte function-associated antigen-3 (LFA-3) expression and not with the CMV-induced down-regulation of cell surface class I HLA. J Immunol. 1998;161(5):2365-2374.

30. Barrett AJ. CMV: when bad viruses turn good. Blood. 2011;118(5): 1193-1194.

31. Yi ES, Kim YJ. Cytomegalovirus infection according to cell source after hematopoietic cell transplantation in pediatric patients. Yonsei Med J. 2012;53(2):393-400. 


\section{Publish your work in this journal}

OncoTargets and Therapy is an international, peer-reviewed, open access journal focusing on the pathological basis of all cancers, potential targets for therapy and treatment protocols employed to improve the management of cancer patients. The journal also focuses on the impact of management programs and new therapeutic agents and protocols on

patient perspectives such as quality of life, adherence and satisfaction. The manuscript management system is completely online and includes a very quick and fair peer-review system, which is all easy to use. Visit http://www.dovepress.com/testimonials.php to read real quotes from published authors.

Submit your manuscript here: http://www.dovepress.com/oncotargets-and-therapy-journal 